глубокую связь с богослужебно-певческой традицией, и особенно - с творческим наследием композиторов Нового направления: А. Гречанинова, А. Никольского, П. Чеснокова и других, имея в виду синтез роспева, народной песенности и профессионального музыкального искусства. В духовном концерте «Богородичные песнопения» также предстает и облик современного композитора, автора духовной музыки, для которого грамотность в богословских вопросах, знание и понимание богослужебно-певческих традиций органично сочетаются с понятиями сердечной чуткости, участливого отношения к таким извечным понятиям, как сострадание и совестливость, красота и доброта, любовь и человечность.

\section{Список литературы}

1. Андрей Микита о современных технологиях и храмовой музыке [Электронный ресурс]. - Режим доступа: http:// www.pravmir.ru/andrej-mikita-o-sovremennyx-texnologiyaxi-xramovoj-muzyke-audio/

2. Хватова С.И. Православная певческая традиция на рубеже XX-XXI столетий. - Майкоп, 2011.

3. Гарднер И. Богослужебное пение Русской православной церкви. Т.1. - Сергиев Посад, 1998.

4. Холопова В.Н. Музыкальные эмоции. - М., 2010.

5. Карастоянов Б. Тонемы и просодемы знаменного роспева // Первый всесоюзный семинар по машинным аспектам алгоритмического формализованного анализа музыкальных текстов. Материалы. - Ереван, 1977.

УДК 792.56.03(44)

ББК 85.335 .43

\title{
А.Г. КОЛЕСНИКОВ
}

\section{ТАНЕЦ В ОПЕРЕТТАХ ФРАНЦА ЛЕГАРА}

Статья посвящена роли и значению танца в сценических сочинениях классика неовенской оперетты Франца Легара. В данном аспекте анализируются оперетты «Веселая вдова», «Фраскита», «Джудитта», зингшпиль «Фридерика». Ставится проблема их интерпретации режиссерами и хореографами.

Ключевые слова: неовенская оперетта, музыкальная драматургия, композитор, сценический танец, хореография, интерпретация, Легар Ф.

T

анцевальная музыка в творчестве классика неовенской оперетты Франца Легара появляется на ранних этапах композиторской деятельности, носит преимущественно прикладной, почти утилитарный характер и связана с его 17-летней службой армейским капельмейстером. В культурной политике Австро-Венгерской монархии это положение весьма значимое. Стоящий во главе полкового оркестра не просто универсальный музыкант, обязанный писать музыку, оркестровать, муштровать коллектив, овладевать обширным репертуаром для обслуживания военных парадов и плац-концертов и пр. Лучшие из капельмейстеров становились, по сути, музыкальными директорами города, где дислоцировалось их подразделение.

Молодой Легар, выпускник Пражской консерватории по классу скрипки (1888), затем первый концертмейстер театрального оркестра в Бармен-Эльберфельде (ныне Вуперталь, Германия), возглавлял оркестры в Лошонце (Венгрия), Поле (Хорватия), Будапеште, наконец, Вене и повсюду преображал службу в творческий акт. Переход к театральной карьере совершается органично. Композитор приносит с собой огромный опыт современной музыки, очень высокое оркестровое мастерство, жанровое многообразие - в нем танец не только не теряется из виду,

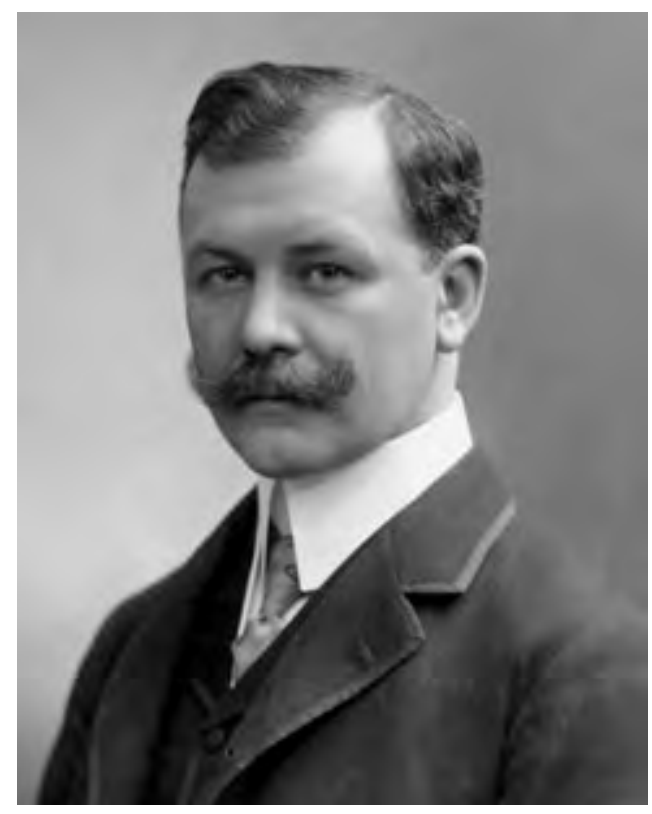


но полноправно вводится в драматургию и поэтику оперетты. С появлением Легара (после смерти К. Целлера, И. Штрауса и К. Миллекера) оперетта выходит на новый уровень своего развития. Венская оперетта становится неовенской.

Уже в ранней опере «Кукушка» на русский сюжет (1896, Лейпциг) композитор дебютирует не столько как мелодист, сколько как музыкальный драматург. Во вторую редакцию оперы (1899, Будапешт) им включен «Русский крестьянский танец». Густав Малер, в то время директор Венской Придворной оперы заинтересовался сочинением, потом отклонил как ученическое, но выразил намерение заказать Легару балет. Как пишет Ю. Стерн, Малер считал, что «сегодняшняя оперетта и танец родствены, прямо-таки тесно друг с другом связаны. Он верил, что сильное влечение к опере у Легара будет укрепляться, в особенности, если бы он предложил более тонкую музыку и особенные ритмы» [1]. Неизвестно, было ли доведено предложение до Легара. Известно, что переселившись в Вену в последний год жизни И. Штрауса (1899), Легар вовлекается в интенсивную артистическую жизнь.

«Веселая Вена» еще сохраняет миф о самой себе, однако все больше и больше возникает ощущение призрачности города. Иллюзорность и отмирание начинают культивировать в своих сочинениях австрийские писатели Гуго фон Гофмансталь и Артур Шницлер, вслед за ними чувство трагической неизбежности появляется в сочинениях Йозефа Рота, Стефана Цвейга, Роберта Музиля и других авторов. И в сочинениях Легара появляются меланхолия и сомнение, особенно явные при сопоставлении его вальсов со штраусовскими. В его новых венских вальсах, тех, что вскоре станут частью музыкально-сценической формы оперетты, Легар отказывается от расхожих любовно-сентиментальных и романтических трактовок. Вальсы перестают быть пьесами бытового характера, они наполняются загадочным психологизмом, манящими нюансами, часто темными и непонятными, извлеченными из подсознания. Людвиг Доблингер издает «Альбом новых венских вальсов» Легара (1902), в который вошел сыгравший важную роль в судьбе композитора «Паулинен-вальс» (опус 70). За ним, в 1902 году, последовал созданный также в честь княгини Паулины фон Меттерних-Сандор (внучки канцлера Клеменса Меттерниха) и по ее заказу вальс «Золото и серебро» (опус 79). Находясь в рамках салонного заказа, Легар выходит за их границы и предлагает программное художественное высказывание в форме вальса.

Маленькая сюита в традициях трехчетвертной мелодики: шесть самостоятельных тем в простой последовательности обрамлены вступлением и финалом. Так писали и раньше. Но здесь более активное развитие драматургии настроений, направляющих мысль в метафизическое пространство. В «Золоте и серебре» опробовано и прозвучало то, что в дальнейшем станет характерным для метода Легара. Через вальс и иные танцевальные жанры (польку, гавот, марш, канкан, танго, хабанеру, болеро, лендлер, галоп, др.) проступает сложный рисунок взаимоотношений героев; выявляются подтексты; то скрыто, то явно звучит лирический голос автора. Здесь уже присутствуют эмоциональные и формальные константы композиторского мышления, авторские идиомы, коими будут отмечены его сценические творения: психологизм и эротика, потаенная страсть и меланхолические грезы, моментальная перемена настроений и ритмов в пределах одного творческого задания (арии, дуэта, ансамбля, танца, действенной сцены).

В девятиминутной увертюре дебютной оперетты «Венские женщины» (1902, Театр ан дер Вин) маршевое вступление и вальс находятся в жанровом диалоге. Медленный вальс, принадлежащий героине Кларе (№ 5, F-dur), зазвучит всеобъемлющей темой оперетты. Второму вальсувоспоминанию (F-dur) отведена сюжетообразующая роль. Героиня накануне свадьбы слышит романтическую тему настраиваемого в соседней комнате рояля и понимает, что ее наигрывает давно исчезнувший учитель музыки, это вальс их первого чувства. Так у Легара складывается метод драматизации танцевального жанра, который в дальнейшем композитор будет использовать неоднократно. В «Шуточной свадьбе» (1904, Театр ан дер Вин) этот мотив служит сатирическим целям: вернувшийся из Америки в Европу герой демонстрирует тамошние достижения - дикарский яванский танец с обезьянними движениями (так впоследствии будут показывать шимми герои «Баядеры» И. Кальмана). В «Троеженце» (1908, Театр ан дер Вин) в пятичастном финале первого акта (№ 7) монтируются аллегро, марш, вальс - как нечто объединяющее настроения венских туристов, рвущихся за удовольствиями в Париж. Здесь заявлен один из прообразов будущего легаровского театра: танцовщица Жиголетт, чьи ноги заменяют ей ум, а поцелуй сжигает сердца и кошельки в пепел. При повторе темы рядом с «искусницей» возникнет и ее товарищ Жиголо. Намечающаяся типология неовенской оперетты так или иначе связана с танцем, вокруг него разрабатывается и его настойчиво оформляет.

Можно ли счесть случайностью и чем объяснима склонность к танцу как способу художественного высказывания композитора? Безусловно, здесь решающую роль играет фактор Вены, закрепившей танец как эстетическую ценность в культурном обиходе и в социальной психологии. А также личная предрасположенность Легара, о чем известно из воспоминаний Веры Макинской-Кальман, жены другого классика оперетты Имре Кальмана:

«Я безумно любила танцевать, а Имре, как известно, не танцевал.

В таких случаях меня всегда выручал Ференц Легар. Будучи по возрасту старше Имре, он, тем не менее, предлагал:

- Пойдемте в бар, потанцуем немного.

И мы танцевали. Легар был превосходным партнером» [2, с. 188].

Легар специально не формулировал каких-либо воззрений на роль танца в оперетте. Он опытным пу- 
тем постигал его законы, вводя в практику иные нормы сценарной драматургии, типологию персонажей, что в целом кардинально изменило эстетику жанра. Вместе с тем, из самого легаровского музыкально-драматургического материала вполне концепиируются принципы хореографии, ее роль в претворении замысла. Наиболее антологичной предстает «Веселая вдова» (1905, Театр ан дер Вин). В этой ранней и наиболее известной вещи, как в зерне, было заключено многое и со временем проросло, развилось в устойчивые авторские идиомы.

Каково же это сочинение с точки зрения наличия в нем ресурсов танцевальности, хореографических поводов и, главное, с какой целью автор настойчиво вводит танец в художественную систему произведения?

Прежде всего, танец определяет стилистический профиль оперетты, заданный Легаром через танцевальный порядок ${ }^{1}$. Если стилистической основой и камертоном первого акта становятся бальные танцы - вальс и мазурка, то в третьем акте, в ресторане «Максим», композитор использует кафешантанные канкан и кек-уок. Во втором акте между ними как противопоставление одному и другому - народная музыка, почти нестилизованная, а приближенная к фольклорной мелодике и тембрам. Здесь и черногорская сюита, и венок славянских танцев как переживание истинного, присущего всем без различия положений и званий.

Короткая интродукция открывает первый акт (посольство Пентевердро в Париже) быстрым галопом, переходящим в марш (оба G-dur). Виконт Каскада обращается к барону Мирко Зете с благодарностью за дивный прием. Хор вступает с величальным приветствием. Барон отвечает прочувствованным монологом. Хор повторяет сказанное и торопит переход от словесной дипломатии к танцам - всеобщее движение подчеркнет вступающая мазурка (в тональности галопа G-dur) и увлечет общество в соседние залы. Эти несколько страниц интродукции никак нельзя считать формальным введением в оперетту. В них автор приоткрывает содержательные намерения и устанавливает опорные жанровые ориентиры: танцевальность и оптимистическую веселость. Преобладающий в дальнейшем темп Allegro (быстро, весело) соответственно окрашивает историю вдовы и ее миллионов. Галоп и родственный ему канкан, марш, мазурка и вальс выступают в «Веселой вдове» не только танцами как таковыми (вставные номера), но авторским высказыванием в форме танца ${ }^{2}$. Характер и ритм бальных и народных танцев портретируют героев без дополнительных словесных объяснений, намечают мотивацию поступков, рождают те или иные переживания и действенные реакции.

В первом акте (по ремарке на продолжающемся приеме) оркестр за кулисами играет вальс (D-dur).

\footnotetext{
${ }^{1}$ На эту специфику оперетты необходимо обратить особое внимание постановщикам.

2 Эта особенность сценического мышления Легара прочно закрепится в его поздних сочинениях, станет едва ли не главным музыкально-драматургическим приемом композитора.
}

Выход героини (№ 3) строится по схеме: мазурка вальс - мазурка (A-D-A). В финале акта (№ 6, G-dur) звучит так называемый Ballsirenen (призыв, звуки бала) - двухчастный вальс для солиста с хором, вовлекающий в движение персонажей и массовку. Момент всеобщей связанности, всеобщего участия в событиях пьесы также готовит другой - главный вальс героев во втором акте, который их сблизит. И здесь следует уловить образную стратегию композитора. «Веселая вдова» не имеет сквозной музыкальной драматургии в классическом выражении (развитый тематизм, контрастность сопоставлений и пр.). Номера формально обособлены, тематические арки возникают дважды и связаны с темой графа Данило (ресторан «Максим»). Но оперетта обладает, тем не менее, удивительной цельностью - именно из-за точного драматургического значения и положения каждого номера; а также музыкальных характеристик. С появлением нового лица обновляется интонационная сфера, музыка постоянно откликается на меняющуюся ситуацию и заставляет следить за зигзагами душевных приключений героев. Так и в бальной сцене: после отзвучавшего Ballsirenen Данило - наедине с Ганной; получив ее отказ на приглашение к танцу, он начинает танцевать с воображаемой партнершей. Шутка смягчает Ганну: «0н меня победил...». И новый прилив вальсовой темы буквально устремляет их друг к другу.

Во втором акте становится особенно очевидной связанность действия с танцем, усиленная к тому же фольклорной составляющей. Польская музыка, черногорская, южно-славянская и венгерская оформляют собирательный и опоэтизированный образ места - балканского региона. Предшественники Легара (Целлер, Миллекер, И. Штраус) работали с народным мелосом, главным образом через его стилизацию, обработки и переложения. Это общий метод трансформации живого фольклора для сцены. «И венский вальс, - пишет М. Чаки, - и преображенный цыганской музыкальной традицией венгерский чардаш, и богемская (чешская) полька уже тогда были “стилизованными" формами выражения народного музыкального мышления; благодаря им, у горожан складывалось некоторое - пусть даже не вполне соответствовавшее действительности - представление о первозданной атмосфере народной жизни. Можно сказать, что здесь имело место нечто вроде “музыкального остранения", которое очень часто создавало, по существу, искаженную картину реальности» [3, с. 267-268].

Фольклорная компетентность Легара вне сомнений, ибо в фольклоре - его истоки как композитора. Но в «славянском» акте «Веселой вдовы» он понимает фольклор отнюдь не как вставной, экзотический элемент, но как лирическую доминанту действия. Формально дивертисментная природа славянской сюиты посреди Парижа приобретает более глубокое значение, затрагивает более широкие эмоциональные сферы, нежели предписывает внешний сюжет.

Сцена в парке Ганны представляет собой большой инструментальный, вокальный и танцевальный комплекс 


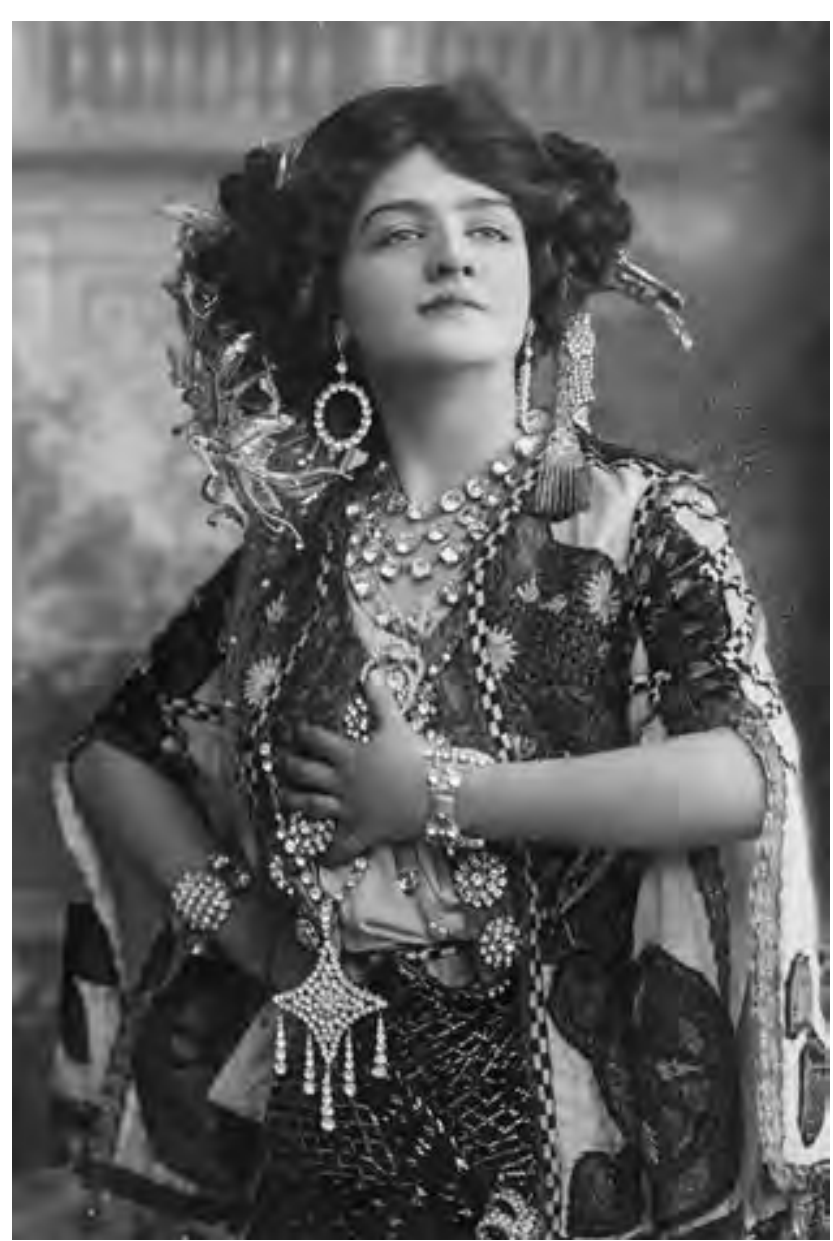

Лили Элси, «Веселая вдова», 1907 г.

(№ 7). Первой взрывается огненная черногорская пляска (D-dur). Сочетание «балалаечного» пиццикато у струнных с тамбуринами, скандированные выкрики хора словно подстегивают прыжковые комбинации танцующих. 3а ошеломляющим эффектом черногорцев - лирический хоровой вокализ (g-moll) затопляет собой пространство и начинается старинный хоровод коло. Вокальные линии хора переплетаются с балетными по принципу прямого соответствия. И вновь - возврат к бешеным ритмам воинственного танца и венчающему все хоровому возгласу. Построение сцены, активный мелодический сдвиг и колорит, ритм и инструментальное богатство должны, вне сомнений, откликнуться в сценическом действии. «Фольклор против рафинированности, музыкальная наивность против сверхкультуры, экзотика против венского элемента, - пишет Э. Дэчей. - И все это смешано в едином новом, незнакомо переливающемся общем тоне, который завоевал мир» [4, с. 82-83]. «Мерцающее, тремолирующее облачение в духе Пуччини пронизывает мелодические находки...», - написал другой автор С. Чех [5, с. 72]. И здесь напрашивается совершенно определенный вывод: помимо интернациональной природы дарования, улавливающей и впитывающей музыкальные токи народной культуры, сюитой второго акта «Веселой вдовы» композитор словно отвечает автору знаменитых «Славянских танцев» и своему учителю Антонину Дворжаку, раньше всех сказавшему студентускрипачу, почти подростку: «Повесь скрипку на стену и сочиняй». М. Шёнхерр предельно прям: «Можно с уверенностью утверждать, что создателем партитуры “Славянских танцев" Дворжака вполне мог бы быть Комзак или Легар, чего не скажешь о Зуппе, Миллёкере или Иоганне Штраусе!» [6, с. 98].

0тголосок венгерского чардаша и воинственного, немного помпезного вербункоша (вербовочных песен) прослушивается в начальных строках дуэта Ганны и Данило «Глупый рыцарь» (№ 8). Здесь намеренно акцентированы первые доли тактов, использованы валторновые форшлаги, введен тембр медных духовых инструментов и барабанный бой, утяжеляющие фактуру. Их шутливый поединок может и должен иметь оригинальную поддержку в танце. Таков же и марш-септет «Дамы, дамы...» (№ 9), буквально зовущий к танцу. В нем слышится отсыл к оркестровой манере «Марша Радецкого» Иоганна Штраусаотца, музыкального символа Империи, буквально побуждающего к движению.

Центральный дуэт Ганны и Данило (№ 10) - чувственный, иллюзорный, рождающийся из зыбкого состояния искренности, из невысказанного - один из самых стойких мифов после Иоганна Штрауса, по выражению А. Иняхина, «лирическая тайнопись» [7, с. 21]. Следующий этап отношений: герои идут по парку (прелестное Allegro D-dur), разговаривают, узнают друг о друге подробности - граф Данило, оказывается, посещает ресторан «Максим» (звучит реминисценция его выходных куплетов). И затем переход собственно в вальс (Moderato G-dur) - начало главной темы, которая словно начинает сокращать дистанцию между ними: медленный вальс (бостон) с выдержанной, утяжеленной первой долей, будто нагруженной внутренним сомнением, неспешное развитие и постепенное ускорение темпа. После небольшого развивающего эпизода звучит повтор главной темы. Ганна и Данило поют ее на закрытом звуке и начинают танцевать. Голоса становятся инструментами и обращаются в танец. Никогда еще в жанре оперетты музыка не устанавливала столь тончайшую близость между людьми. Этот короткий фрагмент на премьере оперетты стал для зрителей настоящим потрясением, они потребовали исполнить дуэт трижды ${ }^{3}$.

\footnotetext{
${ }^{3}$ Весь последующий путь жанра оперетты был освящен этим открытием. Интимное придыхание, невысказанная тоска, выраженные с помощью вальса, повторялись в сочинениях других авторов как современников Легара, так и композиторов более позднего времени. Через танцевальную музыку, и в частности вальс, шли поиски эстетического кода красоты эпохи расцвета венского модерна, цитировался ассоциативный пароль нового стиля. В британском кинофильме о загадочном полотне Густава Климта «Поцелуй» (производство ВВС, режиссер Джон Буш, ТВ «Культура», 2008, 2009) происходит вполне обоснованное сближение музыки Легара и таинственного абриса нового чувствования. Можно также вспомнить включение легаровского вальса в фильм Лукино Висконти «Смерть в Венеции» (эпизоды в гостиничном холле), там он становится мотивом, корреспондирующим главному музыкальному эквиваленту происходящего - Адажиэтто из Пятой симфонии Малера.
} 
Второй финал «Веселой вдовы», будучи сложной многофигурной драматической сценой (№ 12), содержит следующий танцевальный момент. Ганна отвечает на прозрачные и в общем оскорбительные для женщины намеки Данило неожиданным, бурным vivace - ответным залпом в форме марша. Но маршеобразная основа, как правило, скрадывается; наступательная и более размеренная тема сменяется второй в непривычно быстром темпе и откровенно вакхического содержания: марш переходит в форменный канкан. Ганна поет о Париже, провоцирующем свободу отношений - ведь о ней распевал знаменитые куплеты Данило. Помимо выпада в его адрес, здесь еще два скрытых посыла, связанных с танцем как способом художественного высказывания: перекличка с оффенбаховским канканом из «Парижской жизни» и смысловая арка с мужским маршем-септетом «Дамы, дамы». И, наконец, гимн парижским удовольствиям предвосхищает третий акт - в ресторане «Максим».

В его атмосферу вводит опять-таки танцевальная сцена (№ 13) - марш, близкий по стилистике кек-уоку (C-dur). Официанты исполняют «танец пирога», вынося сладкие блюда на вытянутых руках 4 . За ним ансамбль Валентины с гризетками (№ 14). В маршевом начале номера (D-dur) хореографически показаны методы охоты на зазевавшегося мужчину: юбки распахиваются, ножки выставляются, ручки делают смешное «цап-царап». В припеве (G-dur) канканирующая компания воздает хвалу любимому «Максиму». Все это сделано элегантно, не без иронии, что снимает любые упреки в пошлости. Музыка в данном случае не жанровое изобразительное средство (места действия, ситуации), но средство выражения авторского отношения к героям. Ни у кого из современников Легара танцевальный жанр не связан столь тесно с драматургическим содержанием. Танцевальная музыка повлекла за собой изменения в сценическом действии, танец стал его частью. И это оказалось одним из поворотных пунктов преобразования эстетики жанра оперетты.

Важной в контексте обозначенной темы и никогда не попадавшей в круг внимания исследователей можно считать волшебную сказку «Петер и Пауль едут в сказочную страну» (Peter und Paul reisen ins Schlaraffenland), единственную в обширном творчестве Легара детскую оперетту (1906, Театр ан дер Вин). Два брата-подмастерья Петер и Пауль, движимые мальчишеской жаждой приключений, бегут на поиски дивной Шлараффии (Schlaraffenland страна молочных рек и кисельных берегов), аналог Конфетенбурга, кукольного царства сластей и марципанов у Эрнста Теодора Амадея Гофмана в новелле «Щелкунчик и Мышиный король». Злой дух коварства и лени Шлендрианус приводит их к цели. Мальчики проходят ритуальные испытания (как в «Волшебной флейте»), являют чудеса вранья и обжорства и становятся полноправными гражданами в краю вечного наслаждения. Беглецов спасает

${ }^{4}$ В некоторых трактовках выливается в самостоятельный изящный спектакль.

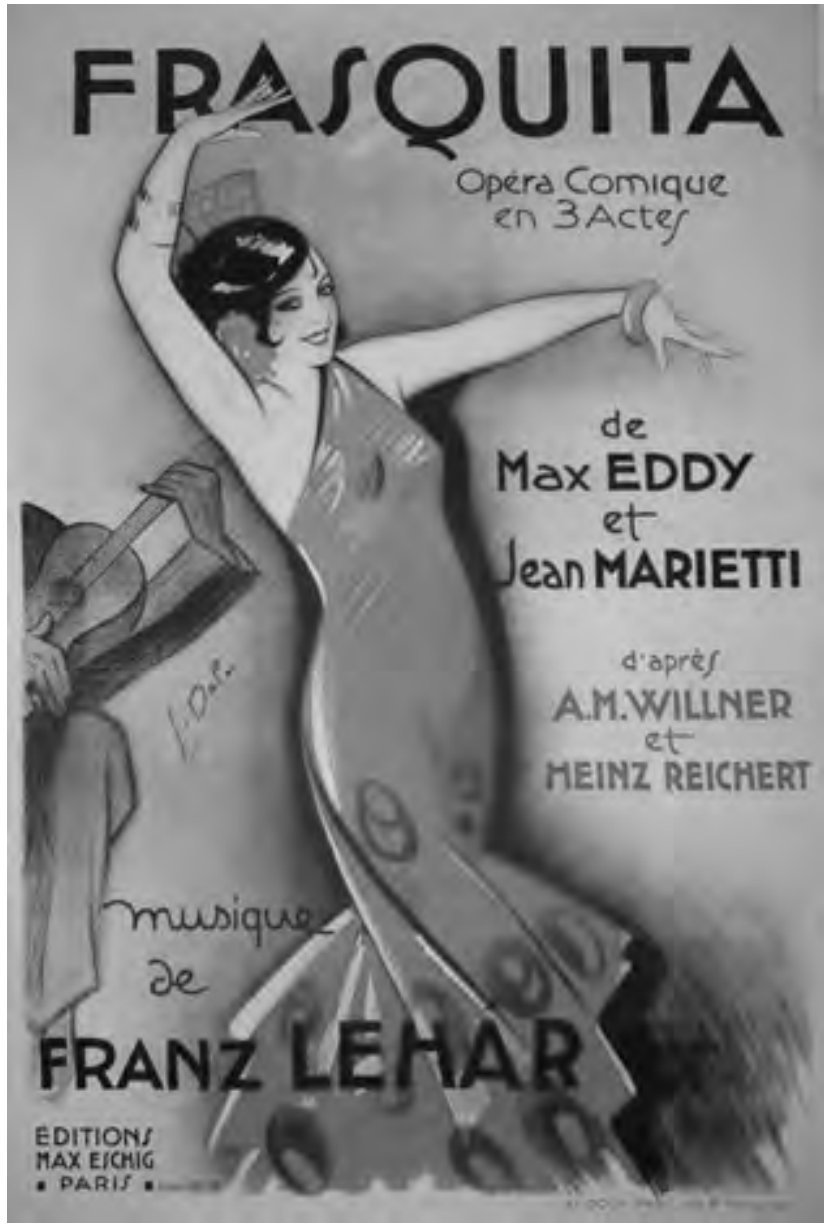

Афиша, 1933 г.

фея добра и трудолюбия Лабороза. Посрамленные и раскаявшиеся они возвращаются к родному очагу под Рождество. Особую щедрость композитор проявляет в большом балетном дивертисменте, сравнимом по масштабу и разнообразию с сюитой кукол в «Щелкунчике» П. Чайковского. Девять разнохарактерных номеров: «Гвардейский марш», «Вальс красных маков», «Пряничная полька», «Акробатический галоп», «Свадьба зеленых овощей», «Терцет и танец поросят», «Игра-гавот», «Петушиные гонки», «Пчелиный вальс». И - совершенно в духе старинных дворцовых балетов - «Заключительный апофеоз» в честь сиятельных бездельников короля Шлампамприуса и королевы Галатеи. Уникальный детский альбом Легара пример беспрецедентной свободы автора, не чуждого иронии и самоиронии, смешивающего народную основу сказки с актуальными венскими аллюзиями, а также развернувшего протяженную балетную сюиту из далекого мира детства, куда уже никому не вернуться.

«Веселая вдова» имела огромное значение для самосознания европейского музыкального театра. Но и в дальнейшем хореография не уходила из круга внимания автора, ее роль в ряде сочинений продолжала быть ощутимой, а в иных главенствующей. Драматизированный вальс - основа «Веселой вдовы». Марш и канкан «Венских женщин» и той же «Веселой вдовы». Чардаш - 
«Цыганской любви»; мазурка - «Голубой мазурки»; танго - «Королевы танго» и «Танца стрекоз»; менуэт и лендлер - «Фридерики»; хабанера и болеро - «Фраскиты» и «Джудитты». Танцы в национальном (квазинациональном) стиле введены в сюжетный фон оперетт: «Там, где жаворонок поет» (венгерские), «Идеальная жена» (испанские), «Царевич» (русские и черкесские); «Желтая кофта» и «Страна улыбок» (китайские), «Паганини» (итальянские), и т. д. Во всех случаях танец в своем прямом назначении (дансантности) или как его ассоциативный образ вплетен в художественную ткань произведения.

Иногда это сюжетообразующий фактор, как в «Голубой мазурке» (1920, Театр ан дер Вин) - знакомству героев на балу сопутствует мотив мазурки, и после кратковременной размолвки он же их соединяет. Сходное сюжетно-конструктивное назначение у вальса в «Венских женщинах», о чем уже было сказано.

Чаще всего Легар использует танцевальный жанр для характеристики персонажа в том или ином смысловом ключе. Терцету-чардашу Илоны, Иоланты и Каэтана в «Цыганской любви» (№4) присущ пародийный характер опытная дама дает мастер-класс любовного обхождения молодому увальню. Дуэт Джульетты и князя Базиловича из «Графа Люксембурга» (№ 13) «Был я в салонах львом» написан в ритме и настроении польки; в нем использованы славянские обороты. Терцет-полька князя Базиловича, Джульетты и Бриссара (№ 16) юмористичен: младость и зрелость вступают в комическую перепалку; галантность прошлого и новые скорости сопоставлены в остроумной игре ритмических и интонационных контрастов. Номера эти нельзя лишь пропеть - их эффект в соединении пения с танцем. Эта истина, на сегодняшний день не требующая доказательств, добывалась Легаром на практике и вводилась в обиход. Типологическое открытие - вторая пара, простак и субретка. Почти все их дуэты выражают восторг жизни через танец (полька, вальс, галоп). Характерные и возрастные персонажи не сразу, со временем наделяются сольным номером с танцем.

Есть у Легара и более сложные формы танцевальной семантики, когда танец, имеющий внешне дивертисментное значение, корреспондирует с остро драматичными линиями судьбы героев, составляет смысловой контрапункт. В этой связи особенно интересны поздние оперетты Легара, в которых он - создатель неовенского канона - нередко ставит его под сомнение, как бы осознает его относительную исчерпанность и пытается перестроить изнутри. Противоречиями отмечены почти все его работы 1920-х годов, что, однако, отнюдь не делает их недостаточными в музыкальном отношении. Наоборот, поздние легаровские шедевры, исполненные трагизма и неразрешимости, знаменуют важный эволюционный поворот в эстетике неовенской оперетты - к музыкальной драме как таковой, или «легариаде». А в логической перспективе к мюзиклу.

Зингшпиль «Фридерика» (1928, Берлин, Метропольтеатр) написан о юношеском любовном романе Иоганна Вольфганга Гете к Фридерике Брион. В эпизодах «Зазен- геймской идиллии» 1771 года мы видим Гете танцующим, и это не допущение авторов, но автобиографическая подробность из «Поэзии и правды». В партитуре, одной из самых совершенных у Легара, танцевальный жанр также прочно слит с драматическим действием. В первом финале (№ 8) студенческая братия неистово танцует, требуя вина, а в это время решается судьба влюбленных, тесно связанная с загово́ром - запретным поцелуем. Происходит драматическое напластование мотивов и голосов на фоне танца.

Антракт ко второму действию «Фридерики» (№9) в страсбургском салоне мадам Шолль открывается великолепным менуэтом, - гайдновским по классической стройности, стилистической безупречности оркестрового письма. Но это больше, чем стилизация или одно лишь оркестровое мастерство. В менуэте иной ракурс эпохи, контрастный простоте и бесхитростности Зазенгейма. Музыка не просто звуковое пиршество, но скачок в иное культурное пространство, что, конечно, имеет внятную драматургическую цель. И она откроется во втором финале, в протяженной, многофигурной и драматической сцене расставания. А формальным поводом к нему послужит отказ Фридерики протанцевать с Гете (как в картине деревенского бала «Евгения Онегина»).

Третий акт содержит еще два, собственно танцевальных включения: пфальский танец (№ 18) и рейнский лендлер (№ 18 ). Помимо наслаждения грацией музыки, редкими звуковыми, интонационными и ритмическими эффектами, они весьма драматургичны, становятся частью действия, его контекстом и контрапунктом. События 150-летней давности реконструированы Легаром через патриархальные формы национальной культуры - музыку и танец.

«Фраскита» (1922, Театр ан дер Вин) написана на гребне славы, но и в переломный период, обозначивший новые подходы к драматургии. «Джудитта» (1934, Венская государственная опера) - последнее сценическое сочинение Легара, собравшее воедино как на обозрение его эстетику и одновременно ее кардинальная ломка, возможно, в преддверии новых устремлений. «Фраскита» еще оперетта, но буквально исчезающая на глазах. «Джудитта» - музыкальная драма, не оставляющая надежд на воскрешение былой легкости и бесконфликтности. В центре обоих произведений - женщины, чья эгоистическая устремленность к любви несет гибель окружающим. И та, и другая героини имеют отношение к танцу: цыганка Фраскита поет и танцует. Джудитта - по сюжету - становится певицей и танцовщицей, что непосредственно отражается на музыкальных характеристиках, определяет лейтмотивы любовных драм и кульминационные моменты, приводящие к поворотным событиям.

Любовная песня Фраскиты (№ 5) в манере и ритме хабанеры строится на прихотливом, изощренно гибком чередовании нескольких мотивов. В дальнейшем, приобретя самостоятельное значение, эти мотивы будут попеременно возвращаться подголосками, значимым контрапунктом, 
острыми звуковыми сигналами о том хаосе, что творится в ее душе. Связь пения с танцем удивительная. Одно без другого немыслимо и не будет «работать». «Танец Фраскиты возникает из ее природного чутья, - считает Б. Грун, - она танцует ненависть и преданность, ярость, жар, горесть, надежду, торжество - она танцует джакару, триану, фанданго и сапатеадо, вакхический испанский и мягкий парижский вальсы: и пока она танцует, вы начинаете понимать ее, и она становится человечней и привлекательней» [8, с. 185].

Танцевальные ритмы и мотивы становятся сквозными в трактовке образа Джудитты. Продолжительная 12-минутная сцена знакомства с Октавио (№ 5), фрагмент «In einem Meer von Liebe» (океан любви) - это танго, в партитуре которого звучат кастаньеты. Происходящая здесь драматизация танцевального жанра оказывается своеобразным предощущением будущего Джудитты как танцовщицы. Наиболее яркая и к тому же роковая роль отведена хиту героини «Meine Lippen, sie küssen so heiß...» (№ 16). Ставшая мелодией века, как и ария Су-Хонга из оперетты «Страна улыбок», она давно утвердилась на концертной эстраде в качестве самостоятельного номера. Джудитта поет о своих губах, целующих горячо, своем теле, живущем автономно от разума. В пении и танце - требование любви, поклонения и главный смысловой сдвиг пьесы: от романтического таинства - к вседозволенности и освобождению от любовных иллюзий. Этим она наносит последний, едва ли не смертельный удар своему возлюбленному. В основу виртуозной арии, написанной в классической двухчастной форме, с ладовой переменностью (e-moll-E-dur), положены танцевальные жанры: первая - болеро, вторая - вальс.

Итак, танцу у Легара отведена особая роль. Постановщикам и хореографам следует осознавать не только дивертисментную, но и специфическую роль танца в том художественном синтезе, которого достигла оперетта в творчестве композитора. Проблема практического воплощения его танцевальной музыки вполне исторична. Имена первых хореографов Иоганна Штрауса неизвестны. Имена первых хореографов Франца Легара уже известны, но они мало что говорят современному читателю. По мере роста популярности Легара в мире, к его творчеству начинают проявлять интерес известные балетмейстеры. Гертруд Боденвизер дважды работала с Легаром в Вене: «Паганини» (1925) и «Царевич» (1928); Маргарита Валльман как главный балетмейстер Венской оперы участвовала в мировой премьере «Джудитты» (1934). А Джордж Баланчин работал над танцами в «Веселой вдове» в Нью-Йорке, в Театре Мажестик (1943). Можно предположить, что танец в опереттах Легара, поставленных в западноевропейских и американских театрах, постепенно приобретал авторскую хореографию5.

\footnotetext{
${ }^{5}$ Российский путь в тот же период по тому же принципу не проследить. Он просто не дает повода к обобщениям. Роль самого танца долгое время и практически повсеместно аккомпанирующая. В рамках сложивших-
}

Эмблематичность легаровской музыки для европейской культуры XX века стала фактом. Танец в его сочинениях стал больше, чем просто танец: он занял важнейшее положение и предстал самодостаточным и самоочевидным эстетическим феноменом.

\section{Список литературы}

1. Stern J. Volkszeitung. - Wien. 9.3.1924.

2. Кальман В. Помнишь ли ты?..: Жизнь Имре Кальмана. - М.: Радуга, 2002.

3. Чаки М. Идеология оперетты и венский модерн: Культурноисторический очерк. - СПб.: Изд-во имени Н.И. Новикова, 2001.

4. Deschey E. Franz Lehár. - Wien: Drei Masken Verlag, 1924.

5. Владимирская А.Р. Франц Легар. Изд. 2, испр. - СПб.: Лань: Планета музыки, 2009.

6. Schönherr M. Die Instrumentation bei Lehár // Lang Andrew. Unterhaltungsmusik aus sterreich: Max Schönherr in seinen Erinnerungen und Schriften. - Bern, 1992.

7. Иняхин А. Танцы в «садах Нерона» // Театральное дело. 2002. - № 2-3 (18-19).

8. Grun B. Gold and Silver. The life and times of Franz Lehár. London, 1970.

ся стандартов опереточного спектакля хореографам не представлялось возможным развить то немногое, что содержали партитуры лучших оперетт. Более или менее заметные прорывы возникают хаотично. В лучших спектаклях оперетты последнего времени, как правило, решаются не просто традиционные постановочные задачи, но, насколько возможно, воссоздается театр Автора, театр Времени. Такие спектакли всегда поставлены на мощной стилевой базе, внутренне сбалансированы, танец возникает в них осознанной необходимостью, востребован логикой действенного развития, авторской волей, даже самим присутствием композитора. Режиссер В. Курочкин и польский балетмейстер Кристиан Грушкувна, ставя «Фраскиту» (1983, Свердловский театр музкомедии), вообще считали ее настоящей балетной сюитой.

Совершенно необычную задачу решал балетмейстер Г. Ковтун в оперетте-феерии Франца Легара «Петер и Пауль едут в сказочную страну» (2000, Краснодарский музыкальный театр, первая постановка в России). Режиссер В. Цюпа оценил оперетту как большую театральную форму, и Г. Ковтун смог реализовать ее редкие возможности в разных танцевальных системах. В пуантной классике - «Пчелиный вальс» и «Вальс красных маков»; средствами пантомимы решалась «Свадьба зеленых овощей», в клоунаде - «Петушиный бой»; в историко-бытовом стиле - «Гавот»; характерными и гротесковыми стали «Пряничная полька» и «Терцет поросят»; «Гвардейский марш» и Финал потребовали действенного танца. 